\title{
Necropolítica da memória escrava no Brasil pós-abolição
}

\begin{abstract}
Resumo
A partir dos usos necropolíticos da memória escrava no Brasil pós-abolição, este ensaio analisa a figura do escravo como um ponto de singularização e acúmulo de uma série de tecnologias de poder (soberanas, pré, proto e ultradisciplinares, bio e necropolíticas) que poderiam oferecer uma grade de inteligibilidade para compreender a governamentalidade colonial e suas relações paradoxais com a abolição e a liberdade. Convocando as relações entre memória, história e intempestivo, e por meio da articulação entre textos do pensamento político ocidental antigo, moderno e contemporâneo, propomos descrever de forma interdisciplinar as relações entre o escravo e o fundamento da autoridade política como lógica de necropoder subterrânea que atravessa as figuras aparentemente díspares do escravo, do imigrante europeu, do trabalhador livre e do empresário de si neoliberal. Conclui-se que o desaparecimento da forma-escravo antiga e colonial não determina o fim da lógica escravista, mas sua difusão generalizada na figura de um escravo informe a que os trabalhadores livres, empresários de si mesmos e imigrantes dão consistência hoje.
\end{abstract}

Palavras-chave: Memória. História Moderna. Escravidão. Abolição. Necropolítica.

\author{
Murilo Duarte Costa Corrêa \\ Doutor em Direito pela Universidade de São \\ Paulo (USP). Professor na Universidade \\ Estadual de Ponta Grossa (UEPG). \\ Ponta Grossa - PR - BRASIL \\ mdc.correa@gmail.com \\ orcid.org/0000-0002-4420-2275
}

\section{Cainã Domit Vieira}

Doutorando em em Ciências Sociais Aplicadas pela Universidade Estadual de Ponta Grossa (UEPG). Professor na Unidade de Ensino Superior Vale do Iguaçu (UNIGUAÇU).

Porto União - PR - BRASIL advocaciadomitvieira@gmail.com orcid.org/0000-0002-6196-2938

\section{Para citar este artigo:}

CORRÊA, Murilo Duarte Costa; Vieira, Cainã Domit. Necropolítica da memória escrava no Brasil pós-abolição. Tempo e Argumento, Florianópolis, v. 11, n. 26, p. 368 - 401, jan./abr. 2019. 


\title{
Necropolitics of the slave memory in Brazil's post- abolition period
}

\begin{abstract}
The necropolitical uses of Brazilian post-abolitional slave memory is set as a starting point to analyse the figure of a slave as a singularized and aggregated set of various technologies of power (sovereingty, pre-, proto- and ultradisciplinary powers, bio- and necro-political estrategies). This could provide us with a comprehensible view of colonial governamentality and of the paradoxal strategies relating this governamental power to abolition and freedom. By using memory and History concerning antique, modern, and contemporary texts from Western political thinking, we unveil the links between slavery and the basis of political authority, ruled by a necropowered hidden logic which apparently constitutes slaves, European immigrants, workers, and neoliberal "self-employed" workers. As a result, this essay states that the vanishing of the antique and modern form of consistuting 'slave' does not put an end to the slavery logic. It does desplace, generalize, and spread this logic upon the pattern of an amorphous slave which is today embodied by regular workers, neoliberal "self-employed" workers, and immigrants
\end{abstract}

Keywords: Memory. Present Time. Slavery. Abolition. Necropolitics.

\section{Introdução: o intempestivo e a memória do tempo presente}

Qual a utilidade e quais os inconvenientes da História para a vida?, pergunta-se Nietzsche (1990) na Segunda consideração intempestiva. Mais do que uma mera denúncia do espírito de gravidade ou da má-consciência em que o exercício individual ou coletivo da memória podem lastrear-se (RICEUR, 2007), a pergunta nietzschiana evoca uma 
translação perspectiva da História em relação à vida, deslocando seu valor canônico, supostamente intrínseco. De um lado, o passado é denunciado como um fardo que as boas consciências não cessam de arrastar atrás de si, como grilhões; de outro, ao colocar a História como elemento indiciário das relações entre a memória e a vida, marcando-o a fogo com o signo do intempestivo, Nietzsche convida a descerrar o extemporâneo como uma força ativa que não cessa de agir no cerne da mais urgente atualidade, como expressão de uma espécie de força subterrânea que move o olhar na direção do tempo presente (BÉDARIDA, 2002; AREND; MACEDO, 2009).

Nesses termos, a memória deixa de ser o que é para o cânone - lembrança veridicativa, pura relação com o passado - para tornar-se, muito mais do que isso, reserva de potenciais de abertura e futurição. Para evocar uma expressão de David Lapoujade (2010), cunhada sob a influência de Bergson, a memória deixa de ser um elemento do passado para tornar-se une mémoire pour le devenir, uma reserva de forças transformativas e ativas capazes de intervir no presente. Visto como matéria de uma memória ativa do tempo presente, o inUsos e abusos da história oral. 5.edtempestivo constitui o elemento imemorial e urgente que pressiona o investigador a ressignificar o passado em função da atualidade (HOBSBAWN, 1993).

Submeter a História à memória e à vida, tomá-la como a última medida de sua utilidade e das suas desvantagens, encerra um gesto profundamente político que, ao mesmo tempo em que anula a memória como um elemento puro do ser do passado, sela o seu valor efetivamente vital. Do ponto de vista da vida, todo uso da memória é imediatamente político, seja este uso necro ou biopolítico. Isso porque a vida e os destinos coletivos permanecem em jogo nas formas canônicas e necromnêmicas (ou intempestivas e vitalistas) com que uma civilização se relaciona com a História - e talvez fosse o caso de reconhecer, como Giorgio Agamben (2008), que uma cultura se define por uma forma privilegiada de experiência do tempo. É a própria vida que está em jogo quando a memória, encerrada sob a forma impotente de recordação diletante, permanece inerme e anulada em seus potenciais intempestivos; isto é, em sua capacidade para arrastar em um devir um conjunto de dados presentes na direção do mais longínquo alhures. 
Recuperar o sentido mais urgente e prático dos usos políticos da memória, especialmente no Brasil pós-abolição, é perguntar-se em primeiro lugar se algo como um Brasil abolicionista pôde um dia existir. Ou se, por outro lado, a imagem (normativa e negativa) de um Brasil pós-abolição não seria precisamente um signo 'das inconveniências da História para a vida' que impedem de conceber que não há Brasil pósabolição porque jamais conhecemos abolição efetiva.

É no contexto da miragem fantasmática de um Brasil pós-abolição e pós-colonial que seria preciso situar a sombra pós-estrutural do escravo e da lógica de governo do potentado colonial. Os empresários de si mesmos - efeitos de subjetivação da racionalidade neoliberal da exploração do trabalho contemporâneo - não passam de um avanço reiterativo e nuançado da lógica colonial que se atualiza formalmente na divisão internacional do trabalho. Os fluxos de migrantes de países ainda mais provinciais na escala planetária que o próprio Brasil - não raro sujeitos a condições de trabalho análogas à de escravos ao chegarem - não passam de substratos corpóreos supranumerários e disponíveis para atualizações contemporâneas de uma lógica de escravismo mais insidiosa, porque está lastreada em um conjunto de liberdades formais.

Eis as linhas de continuidade contingenciais de um Brasil pós-abolição que jamais conheceu efetivamente a abolição. Ou que, sob seu pretexto, funcionou como caixa de ressonância para a reiteração deslocada de suas lógicas mais profundas. Há um Brasil pósabolição, em que a forma-escravidão já não subsiste como tal, embora sua prática efetiva não tenha desaparecido por completo, mas sofrido mutações no tecido dos ilegalismos que recobrem as relações de trabalho e os fluxos de migração internacional. Desse ponto de vista, o Brasil pode ser definido como uma Nação cujo projeto consistiu em uma sucessão de usos necropolíticos (e etnocidas) da memória do colonialismo e do escravismo, impedindo ou governando os usos biopolíticos dessa memória que significaria, senão a sua integral superação, a instauração de um novo horizonte de possíveis políticos - isto é, uma nova relação com a vida. 


\section{Escravismo e poder sobre a vida}

O escravo é a figura que, desde o pensamento político antigo, marca a inscrição da vida orgânica de seres humanos que, não sendo pessoas, assumem o estatuto de coisas ou objetos na dupla lógica da economia e do poder. Entre os sujeitos do mundo antigo, o escravo talvez seja a figura com maior capacidade para descerrar uma espécie de fundamento oculto da autoridade política e também do que viria a ser - já nos esquemas dos Estados-Nação europeus modernos - a estrutura originária do poder soberano.

Quase tudo o que se disse sobre o escravo - exceto pelo estatuto de coisa ou objeto -, Giorgio Agamben (2007) afirmou com precedência sobre o homo sacer. Esta era a figura ambivalente, ao mesmo tempo sagrada e maldita do direito romano antigo, gravada com uma condição de insacrificabilidade - a interdição de ser morta nas formas sancionadas do rito religioso - e de uma matabildade universal, impassível de ser punida como homicídio pelo direito penal comum. Essa condição de dupla exclusão da vida nua matável e insacrificável do homo sacer, segundo Agamben, constituiria o fundamento não revelado da soberania política no Ocidente.

Nesse sentido, o homo sacer aparece como uma espécie de figura reveladora de uma estrutura política mais original que não cessou de se repetir em diversos níveis de realidade no Ocidente, da pólis grega, passando pela soberania moderna e recebendo seu desenvolvimento terminal nas operações tanatopolíticas dos campos de extermínio nazistas. O homo sacer apontaria a persistência de uma estrutura originária já encontrada na pólis grega e que excluía do âmbito político precisamente a vida orgânica e reprodutiva (zoé), definitivamente confinada no âmbito doméstico (oikos) (AGAMBEN, 2007).

O que, todavia, a figura do homo sacer não permite revelar (pelo contrário, oculta) é, de um lado, a realidade encarnada que origina e sustenta essa estrutura política soberana e, de outro, os modos pelos quais sua lógica própria, apesar de estar sujeita a deslocamentos contingentes, poderia encontrar-se no fundamento mesmo da soberania política moderna. Em outras palavras, o que o homo sacer obscurece - ou pelo menos não deixa ver diretamente - é que se há uma figura originária da inscrição da vida nua natural na ordem político-jurídica, e que constitui o "fio vermelho" que liga a antiguidade 
ocidental às experiências soberanas e coloniais dos Estados-Nação europeus na modernidade, essa figura encarnada é a do escravo. ${ }^{1}$

Entre a Antiguidade e a modernidade, o escravismo parece ser a carne e a lógica, o substrato muito material e a racionalidade efetiva de governo que tornam a estrutura da vida politicamente qualificada (bíos) possível entre os antigos, constituindo um fundamento de legitimação da soberania política entre os modernos e os liberais, que não deixa de guardar certa semelhança com o despotès grego.

Ao discutir a configuração da autoridade política na pólis grega, Aristóteles recorda que em algumas cidades era comum que homens livres, mas dotados de "aptidões servis", que se ocupavam de atividades ligadas ao labor - caso dos trabalhadores manuais e artífices - fossem geralmente excluídos das funções de governo, exceto em "democracias extremadas” (ARISTOTE, 1993, p. 219). É nesse contexto que Aristóteles pergunta se os trabalhadores manuais, artesãos, artífices ou homens livres dotados de aptidões servis deveriam ser contados entre os cidadãos. Sua resposta negativa é esclarecedora. Nem todas as pessoas indispensáveis à existência da cidade, afirma Aristóteles (1993), precisam ser contadas entre os cidadãos. Assim, a cidade reserva a exclusividade da atividade política aos homens livres isentos das atividades servis (isto é, ociosos) em razão de que os artífices eram geralmente identificados a alguma das duas figuras excluídas da cidadania, os estrangeiros e os escravos.

Essa prática de exclusão dos trabalhadores livres e manuais da esfera política e da plena condição de cidadania supõe a forma pela qual zoé e bios, mas também oikos e pólis, se articulam sob um modo especial de exclusão a que Agamben (2007), recuperando o sentido etimológico de ex capere (do latim, “capturar fora”), chamará de relação de exceção, a fim de designar "esta forma extrema da relação que inclui alguma coisa unicamente através da sua exclusão". Os termos da relação de exceção, nesse caso,

\footnotetext{
${ }^{1} \mathrm{O}$ próprio Agamben, relativamente distante da discussão sobre a centralidade da figura do escravo nos primeiros volumes do Homo Sacer, só virá a reconhecê-lo mais recentemente, em O uso dos corpos (Homo sacer, IV, 2), postulando uma parcial coincidência entre escravo e vida nua em função da vida política: "[...] o escravo, embora excluído da vida política, mantém com ela uma relação totalmente especial. Ele representa uma vida não propriamente humana que possibilita aos outros a bios politikos, ou seja, a vida verdadeiramente humana. E se o humano é definido para os gregos por intermédio de uma dialética entre physis e nomos, zoé e bios, então o escravo, assim como a vida nua, está no limiar que os separa e une" (AGAMBEN, 2017, p. 39).
} 
remetem simultaneamente às duas dimensões da vida (zoé e bios) e da relação social e política entre os gregos (oikos e pólis), mas nela está em jogo a própria definição da politeia e seu fundamento forcluído - não a vida do homo sacer, mas a vida do escravo. Contra Sócrates, que na República platônica definia a cidade por uma justaposição compósita de muitas classes de trabalhadores cuja função era a satisfação das necessidades comuns dos cidadãos, Aristóteles (1993) afirma que uma cidade não é formada apenas para a satisfação das necessidades materiais da vida, mas para um fim mais elevado.

Tanto na República platônica como na cidade aristotélica, o labor é estruturado como um lugar social no interior de uma ordem pré-constituída, que o situa politicamente em uma zona de exclusão da vida política (ARENDT, 2010). Uma ordem policial, cuja função é impedir o afloramento da igualdade radical que caracterizaria, para Jacques Rancière (1996), a política como possibilidade de reivindicar o lugar dos sem-lugar e a parte dos sem-parte na estrutura policiada da vida em comum. Uma ordem de pessoas e de coisas (aí incluídos os escravos, na estranha condição social e política de "nãopessoas" que termina por fundar sua pretensa ontologia nos marcos da razão Ocidental) em que a repartição entre vida reprodutiva e vida política, reciprocamente isoladas, subordina a zoé à bios e o oikos à pólis, fazendo do elemento doméstico o sustentáculo material necessário (e a condição de possibilidade) do político.

Todas as figuras centrais próprias à vida doméstica grega antiga - as mulheres e os animais, por exemplo - podem ser compreendidas à luz da relação arquetípica entre senhor e escravo. Não apenas por habitarem por excelência o círculo pré ou apolítico das necessidades e da vida reprodutiva, do qual os cidadãos encontram-se isentos precisamente em razão da existência dessa estrutura, mas porque todos os dimorfismos de autoridade que servem de sustentáculo para a pólis grega podem ser reconduzidos a essa relação arquetípica.

Não é raro encontrar na Política uma tal ordem de isomorfias. Segundo Aristóteles, homens e mulheres conviriam em função do impulso natural comum de "deixar atrás de si um indivíduo da mesma espécie". Os laços reprodutivos entre homem e mulher são aqui erigidos sobre bases pretensamente naturais, e sua relação se define como a união 
entre um comandante natural, que "usa seu espírito para prever" (o homem), e um comandado que "usa seu corpo para prover" (a mulher) (ARISTOTE, 1993, [1252a-b]). Aristóteles também compara a relação entre o senhor e o escravo àquela entre um pobre e seu animal, que não passa, para ele, de um instrumento de ação que tem a particularidade de ser vivo (ARISTOTE, 1993, [1252b]). As relações parentais entre pais e filhos (cidadãos presuntivos) também são marcadas por um dimorfismo fundado na incapacidade das crianças para o lógos e pela impossibilidade de fazer uso da razão, da linguagem, do intelecto ou das faculdades de previsão e diligência intelectual que carcaterizam o Noûs.

O espaço do oikos segue inteiramente, embora admita diferenças de grau, a racionalidade do escravismo, sobre a qual a pólis finalmente se erige. E são as características do escravo que, a cada figura da vida privada grega, se podem reencontrar atualizadas segundo uma relação específica de dimorfismo social. O governo da casa pelo despotés envolve governar os escravos, bem como as características escravas de pessoas livres: as mulheres, que como os escravos, por natureza (supõe Aristóteles), usam o corpo para prover porque não podem usar o espírito para prever; os animais que, a exemplo dos escravos, provém com o corpo na condição não de pessoas, mas de ferramentas vivas; as crianças são cidadãs presuntivas e figuras transicionais entre as dimensões do oikos e da polis; seus corpos permanecem temporariamente presos ao círculo doméstico das necessidades, erigido para prover a possibilidade futura da vida política, ao mesmo tempo em que sua marca (comum aos escravos) é a alogia (a despossessão do juízo sobre o que é conveniente ou nocivo, justo ou injusto), a posse da phoné (a voz animal, capaz apenas de comunicar a dor e o prazer) e a impossibilidade do uso da Razão. Por fim, a relação entre o despotés e seus bens guarda, ainda, uma clara correlação com os escravos, definidos instrumentalmente como "instrumento de ação que move outros instrumentos", “um ser humano pertencente por natureza não a si mesmo, mas a outra pessoa", isto é, "um bem" (ARISTOTE, 1993, p. 99-103), ou um corpo sujeito ao uso (somatos chresis) do senhor.

Isso permite concluir que, no mundo grego antigo, é a figura muito material do escravo que exprime a relação política, jurídica e social fundamental da oikonomía grega 
que torna a vida humana e politicamente predicada (bios politikos) possível em função de uma relação de exceção. O escravo é, portanto, uma estrutura política fundamental que, se não permite explicar a relação entre governantes e governados e entre homens livres, permite revelar que uma lógica escravista profunda assombra todas as demais relações que estruturam o oikos. De modo que não é o escravo que se explica pelas relações de conjugalidade, parentalidade ou propriedade, mas precisamente o contrário. As mulheres, crianças, animais ou coisas encontram no escravo sua grade de inteligibilidade comum. São escravos em algum grau e a seu modo.

Essas simetrias entre a autoridade e o escravismo no discurso europeu de fundamentação da política não pertencem apenas à Antiguidade. A seu tempo, o pensamento político moderno e liberal foi pródigo em contradições embaraçosas a respeito da figura do escravo. Não é raro encontrar entre teóricos do Estado moderno que supostamente já haviam superado a concepção de uma escravidão lastreada em bases naturais ou metafísicas, próprias ao pensamento antigo e a suas versões medievais - uma relação mais ou menos evidente entre o direito de conquista, a possibilidade de escravizar os inimigos, transformando-os em súditos, e a fundamentação da soberania política dos Estados-Nação europeus.

Isso se deve não apenas ao fato de que a categoria da soberania política foi erigida sobre o terreno de uma secular discussão sobre a legitimidade e os limites do direito à guerra justa conduzidas pelos príncipes e pela Igreja Católica (VITÓRIA, 2006), mas também (e talvez principalmente) à filiação abscôndita entre as figuras do escravo e do súdito, que paulatinamente originará a do cidadão. Essa relação pode ser entrevista, por exemplo, a partir das duas formas de instituição da cidade. Tanto no Leviathan quanto em De Cive, ao discutir a noção de domínio, Hobbes (2017; 2002) afirma a possibilidade de instituir a cidade (common-wealth), seja por aquisição ou conquista, seja por instituição ou contrato. A aquisição ou conquista dá-se quando uma cidade é instituída pela força, e os vencidos na guerra, evitando e temendo a morte (esse poder sobre a vida exercido tanto pelo poder soberano moderno como de acordo com a relação despótica entre senhor e escravo na antiguidade), sujeitam-se a uma dada ordem civil. Não é acidental, 
portanto, que Hobbes exprima a filiação entre a "origem natural de uma cidade" e a existência de um “poder [de tipo] paterno e despótico”, como o do despotés grego.

Ainda que os vencidos não devam obediência aos vencedores pelo fato da vitória, estão constritos a ela porque consentiram em sua sujeição como condição para permanecerem vivos. Eis o que lhe permite descerrar uma isomorfia que atravessa não só as relações soberano-súdito e senhor-escravo, mas traz à luz a profunda analogia entre a lógica que governa as cidades instituídas pela força, pela conquista e pela vitória na guerra e aquelas originadas por contrato ou instituição, baseadas em um pacto livre sob a pressão do terror intersubjetivo que caracteriza a atmosfera afetiva do estado de guerra: "[...] the Rights and Consequences of both Paternall and Despoticall Dominion, are the very same with those of a Sovereign by Institution; and for the same reasons [...]" (HOBBES, 2017, p. 166).

No Segundo Tratado sobre o Governo, Locke (2005, p. 404) definirá a condição de escravidão como "o estado de guerra continuado entre um conquistador legítimo e um cativo, uma vez que se celebre entre eles um pacto [...]", uma maneira de assegurar a obediência servil de maneira legítima e de subtrair a liberdade do cativo de um poder de tipo ilimitado e despótico. Diferentemente de Hobbes, para quem a um homem é dado o poder de dispor da própria vida e vender-se ou entregar-se em escravidão, Locke sustenta que o pacto e o consentimento não podem fundar a escravidão, nem justificam que homens se subordinem a um poder absoluto e arbitrário que ameace a sua existência.

No entanto, Locke (2005, p. 403) declara que a escravidão é natural e legítima sempre que "[...] alguém, por sua própria culpa, perdeu o direito à própria vida, por algum ato que mereça a morte" e "aquele para quem perdeu esse direito pode [...] demorar-se em tomá-la e fazer uso dessa pessoa para seu próprio serviço [...]”. Tudo se passa, portanto, como se manter um cativo na condição de escravo fosse não apenas a extração de uma série de utilidades de um corpo do qual o senhor se serve, nem mesmo o exercício de um poder sobre a vida de alguém, mas o exercício de um direito de matar lentamente sorvido, esgotando pouco a pouco as potências vivas de um corpo. 
Tudo se passa como se o escravo, ao servir, fosse uma espécie de vida que só pode permanecer viva na condição de sua morte virtualmente pretérita; ou, como quisera Achille Mbembe (2018b, p. 28) uma “morte-em-vida”. Os escravos seriam, pois, prisioneiros capturados em uma guerra justa; perderam sua vida, liberdade e propriedades e, com as últimas, foram excluídos da sociedade civil - cujo fim último, como lembra Locke (2005, p. 456), é a sua preservação. A condição de escravo implica, portanto, não só a exclusão da sociedade civil, mas da sociedade dos homens ou das pessoas, na medida em que o escravo é o corpo que trabalha, que "retira algo do estado em que a natureza proveu" (LOCKE, 2005, p. 409), sem que a obra de suas mãos possa constituir sua propriedade inquestionável - como seria para qualquer outro homem, segundo o jusnaturalismo lockiano.

Entre o pensamento antigo e o moderno, os mecanismos de fundamentação da autoridade política e os conjuntos de homologias assimétricas que ligam o escravo ao trabalhador manual e ao estrangeiro (os não-cidadãos por excelência da pólis grega), mas também às mulheres, crianças, animais e coisas, permitem avançar a hipótese de que entre a soberania e o escravismo - como elemento material e encarnado, mas também como lógica estruturante dos dimorfismos sociais e políticos da tradição Ocidental - há um vínculo que permite descerrar as relações mais profundas das formas de exercício de um poder sobre a vida. Se o escravo é o arquétipo cindido da esfera política que, no entanto, constitui seu substrato material e simbólico, por outro lado a soberania indica uma forma de exercício de poder despótico em que as figuras do escravo, do súdito e do cidadão se indeterminam.

A verdade mais profunda da soberania é o escravismo e, por outro lado, o sentido do escravismo é estruturar a autoridade política soberana, como forma de poder sobre a vida. Se a escravidão for, com efeito, a possibilidade de impor a um conjunto de corpos vivos um uso que não evita a sua morte, mas a produz sob uma gestão diferida no tempo, espoliando sua utilidade econômica, tem-se então uma grade de inteligibilidade conceitual, histórica e materialista para interrogar a relação entre governo e liberdade, colonialismo e abolição. 


\section{Necrogoverno e colonialismo}

A escravidão é uma forma de exercício de poder sobre a vida que a gere em função do seu esgotamento e da sua morte; isto é, a escravidão não é uma alternativa ao direito soberano de gládio, mas a sua expressão diferida; um modelo formal que permite administrar no tempo o direito soberano e despótico de matar. Assim, os cativos não se tornam escravos ao invés de serem mortos, mas para serem mortos sob o modelo efetivo, lento e útil que utiliza o trabalho, a espoliação e a sujeição absolutas como instrumentos necrofílicos. Sob o regime da subordinação escravista - mas também fora dele -, trabalhar não passa de uma forma de morrer a conta-gotas e demoradamente.

Se há uma articulação entre o princípio da autoridade política (modernamente, a soberania) e a escravidão como sua estrutura analógica e dissimétrica fundante, é porque a escravidão é produzida por um regime de subordinação que precisa ser melhor explicado. Enquanto os medievais não cessaram de discutir as condições de legitimidade para a escravidão, os modernos - como Hegel ou Montesquieu -, afirmavam abertamente sua conveniência.

Nos Princípios da Filosofia do Direito, quando Hegel propunha os problemas da pobreza e da acumulação como efeitos intrínsecos de uma sociedade civil que age sem peias ou obstáculos superiores, encontrava aí um limite à própria subsistência do Estado, cindido entre uma plebe que perdia "o sentimento do direito, da legalidade e da honra de existirem graças [...] ao seu próprio trabalho" e uma concentração "em poucas mãos [de] riquezas desproporcionadas" (HEGEL, 1997, p. 208). Ainda que se assegurasse trabalho a essa massa pauperizada, prossegue Hegel, o mercado seria inundado por produtos sem que estes pudessem encontrar consumidores. É uma dinâmica histórica, mas também de mercado, que faria a sociedade ser "impelida para além de si mesma; [...] obrigada a procurar fora de si os consumidores e, portanto, os meios de subsistir, recorrendo a outros povos que lhe são inferiores nos recursos que ela possui em excesso [...]" (HEGEL, 1997, p. 209-210).

É no mar que a indústria encontraria o princípio que a anima, e nas relações de tráfico que produzem contratos como instrumentos que favorecem a cultura e o comércio. A realização do espírito absoluto, a Razão, parece impor a visão de que as 
fronteiras já não separam, mas unem, e de que apenas as grandes Nações podem sentir a força de empuxo do mar. Essa é a condição para que, nos termos de Hegel (1997), advenha o alargamento das relações e a colonização como expediente pelo qual as sociedades civis completas podem relançar-se.

Quase um século antes de Hegel fundar o colonialismo como instrumento para salvaguardar "o que há de universal da particularidade da sociedade civil, sob a forma de ordem exterior [...]", zelando "pelos interesses que ultrapassam os quadros da sociedade" (HEGEL, 1997, p. 211), Montesquieu revisitava polemicamente os problemas da escravidão civil e política - o que nos permite deduzir, no seio de um escravismo de caráter mundial, a forma como ele constitui uma estratégia de governamentalidade que leva em conta a liberdade.

Nos livros XV e XVII de O Espírito das leis, a escravidão aparece situada em função do problema de seu fundamento, mas de tal forma que esta já não pode ser compreendida como uma estrutura relacional interna à casa, relacionada aos âmbitos internos à cidade ou ao Estado. Embora Montesquieu (2005, p. 253) afirme que a escravidão não é boa por natureza, "não é útil nem ao senhor, nem ao escravo", "é tão oposta ao direito civil quanto ao direito natural" (MONTESQUIEU, 2005, p. 255), ela logo ganha contornos geopolíticos lastreados em uma leitura etnocêntrica da experiência histórica e geográfica do escravismo. Ao mesmo tempo, na medida em que reconhece que "a condição do escravo é um pouco pior que a do súdito", deduz-se que o que distancia essas figuras é uma diferença de grau, não de natureza.

É no seio do direito das gentes - historicamente, o primeiro conjunto de normas com aspiração cosmopolita - que Montesquieu encontra a dupla causa da escravidão. Por um lado, "O direito das gentes quis que os prisioneiros de guerra fossem escravos para que não fossem mortos" (MONTESQUIEU, 2005, p. 254) - embora já se saiba que a escravidão não passa de um necropoder estruturado para diferir no tempo o ato soberano de matar; por outro, o direito de escravidão também se fundaria no "desprezo que uma nação tem por outra”, baseado "na diferença dos costumes" (MONTESQUIEU, 2005, p. 255). Ainda que se reconheça que a genuína origem do direito de escravidão estaria na livre escolha pela qual um homem, para sua utilidade, submete-se a um senhor 
eis o que Montesquieu (2005, p. 258), declara como um direito com "origem justa e conforme a razão", é com outra causa - intrinsecamente natural e sugestiva da categoria muito biopolítica de população - que parece produzir uma cisão entre os fundamentos da escravidão civil e política entre os Europeus e os demais povos.

Durante o século XVIII, a população emerge como um problema próprio às técnicas governamentais, não como um conjunto de indivíduos cujas ações seria preciso regular pela lei, mas como "um conjunto de processos que é preciso administrar no que têm de natural [...]" (FOUCAULT, 2008, p. 92), originando uma nova ideologia e uma nova tecnologia de governo que se apoiará na liberdade para implantar dispositivos de segurança capazes de intervir física e economicamente sobre a população como um conjunto natural de processos biológicos, aleatórios, imprevisíveis e de longa duração, em uma escala incompreensível para as disciplinas (FOUCAULT, 2008, p. 62-63). Sem perder sua eficácia, esses deslocamentos nas tecnologias de poder europeias, que mais tarde redundarão em modelos de Estado securitários, previdenciários e de bem-estar, exigem uma releitura pelo viés dos escravizados e colonizados que sustentaram materialmente esses processos.

Montesquieu, nesse sentido, por escrever no limiar desse processo histórico, pode oferecer pistas textuais para iluminar as relações entre escravismo e colonialismo nos quadros de uma razão governamental que, sem poder se confundir inteiramente com a biopolítica das populações europeias, funcionou como sua versão necropolítica (MBEMBE, 2018b).

Pode-se encontrar em $O$ espírito das leis uma demanda por explicar a verdadeira origem do direito de escravidão, devendo estar fundado "na natureza das coisas" (MONTESQUIEU, 2005, p. 257), e Montesquieu responde a essa questão de duas maneiras. Como vimos, por um lado a razão e o direito natural exigiriam que a escravidão fossem uma espécie de lamentável pacto de utilidade pelo qual um homem livremente faz de outro seu senhor, despojando-se. Por outro, a servidão natural é considerada ajustada se limitada a certos países particulares da terra em função de seu meio geofísico natural e da economia do trabalho e da preguiça que tais meios determinam. 
Apesar das "belas palavras" sobre a inutilidade e a injustiça natural da escravidão com que o livro XV é aberto, Montesquieu não apenas aceita o postulado aristotélico de uma escravidão fundada em causas naturais - embora critique o autor da Política por não o demonstrar -, como a confina em certas regiões do globo terrestre. Portanto, Montesquieu (2005, p. 258-259) decretava a escravidão inútil “entre nós”, europeus que vivem em países “onde as próprias razões naturais a rejeitam”, mas natural em países “onde o calor debilita o corpo e enfraquece tanto a coragem, que os homens só são levados a um dever penoso pelo medo dos castigos; [...] ali, a escravidão choca menos a razão. [...] escravos por natureza”, completa, “[...] são estes dos quais acabo de falar" (MONTESQUIEU, 2005, p. 258).

Há, portanto, uma relação entre a persistência de uma humanidade vil, debilitada, preguiçosa e covarde em certas regiões do planeta e o meio naturalmente incivilizado que regularmente a produz pela interação entre um espaço geofísico corruptor das virtudes que caracterizariam a civilização (homens europeus, racionais, tenazes, vindos de extensas terras de um clima temperado) e as leis que, malfeitas, originaram homens preguiçosos, cujo trabalho poderia ser, com vantagens e comodidades, substituído pelo das máquinas. É possível perceber, portanto, que a escravidão nos termos de Montesquieu - que mais cedo afirmava que a fonte da escravidão é "o desprezo de uma nação por outra, fundado na diferença dos costumes" - assume aqui todo o seu sentido biopolítico e cosmopolita.

Já não se trata de imaginar a escravidão como uma relação abstrata entre senhor e escravo, sujeita à voluntariedade do direito natural - o que vale para o europeu das terras de clima temperado em que a escravidão fora "felizmente abolida" -, por não se justificar por uma causa natural. Trata-se de imaginar a escravidão como fato social e político determinado pelas condições de um meio geofísico que forja o caráter laborioso ou indolente, corajoso ou covarde, tenaz ou inconstante de populações não-europeias. A regra natural da razão, da vontade e da reciprocidade que vale para os europeus das terras temperadas, não vale aparentemente para os povos asiáticos, africanos ou ameríndios (MONTESQUIEU, 2005). Para estes, a escravidão é a natureza e o nomos da terra, sem que seja possível discernir (a não ser por uma abstração própria à razão natural 
europeia) se é a terra que instaura o nomos do escravismo ou, pelo contrário, o nomos escravocrata que constitui a terra.

Eis o ponto em que se pode apreender a escravidão não mais como uma relação abstrata entre escravo e senhor, mas como uma tecnologia concreta de governamentalidade colonial de populações no plano global². Nesse sentido, a lei civil desempenha um papel importante, mas situado para Montesquieu. Seja qual for o tipo de escravidão que se encontre, "é preciso que as leis civis procurem suprimir [...] os abusos [...] e os perigos" que uma tal condição encerra. Isto é, seria preciso combater a voluptuosidade dos senhores e a preguiça lasciva dos escravos, precaver-se contra o seu grande número, as revoltas potenciais desses bestializados "inimigos naturais da sociedade" (MONTESQUIEU, 2005, p. 263), garantir que o escravismo fosse uma forma de poder sobre a vida do escravo que lhe garantisse alimentação e roupas, o tratamento de suas doenças e de seu envelhecimento, e que inoculasse nos senhores "as leis do pudor do direito natural", de modo que o seu poder de matar fosse exercido não como amo, mas como juiz: "é preciso que a lei ordene formalidades que façam desaparecer a suspeita de uma ação violenta" (MONTESQUIEU, 2005, p. 266).

As alforrias também encerram virtualidades perigosas. Assim como escravos numerosos não podem ser contidos, uma vez libertos estes "não podem viver e se tornam um peso para a república" (MONTESQUIEU, 2005, p. 267), representando um perigo de sublevações tão significativo quanto havia sob o jugo de seus senhores. É necessário, portanto, todo um cálculo parcimonioso a fim de subministrar as alforrias evitando leis repentinas e gerais. Talvez conviesse, sustenta Montesquieu (2005), instituir leis que favorecessem o pecúlio, permitindo aos escravos comprarem sua liberdade; ou reservar um número limitado e periódico de alforrias destinadas a escravos que, em virtude de sua idade, saúde e ocupação, tivessem meios para viver. As alforrias não se afiguram, portanto, um mecanismo jurídico de emancipação civilizadora de populações

\footnotetext{
${ }^{2}$ Seria preciso lembrar que há uma relação inextricável entre o liberalismo europeu e a expansão colonial que produziu o negro como elemento identitário e governável próprio de uma guerra de raças levada a um patamar transnacional. "[...] o capitalismo", sustenta Achille Mbembe (2018a, p. 309), "sempre precisou de subsídios raciais para explorar os recursos do planeta" e, sob esse ponto de vista, a modernidade não passou de "um outro nome para o projeto europeu de expansão ilimitada que foi implementada durante os últimos anos do século XVIII" (Idem, p. 105).
} 
bestializadas, mas uma técnica de governo em que a liberdade e a natureza efetiva dos escravos participam do problema por excelência da modernidade europeia: governar através da liberdade. Eis o que faz das alforrias os instrumentos jurídicos de uma densa economia de liberdades a serem subministradas, dosadas, geridas, controladas, confinadas, inclusive de modo a evitar a mais radical de todas as liberdades, a de natureza política: “mesmo no governo popular”, adverte Montesquieu (2005, p. 268), “o poder não deve cair nas mãos do baixo povo".

Se as alforrias não passam de um instrumento próprio a uma técnica de governo que toma as liberdades por problema e elemento a ser governado, deveria soar como um erro imaginar o abolicionismo desarticulado da tecnologia de poder que ele distende. Não há, nas alforrias, como não há, na escravidão, algo como um elemento de efetiva liberdade. É apenas na condição de mitologema que a liberdade pode ser um direito, uma condição original ou uma essência - embora ela vá ser tomada pelas técnicas de governamentalidade liberais como um dado natural dos indivíduos. A liberdade só pode ser pensada como um efeito de relações de poder estrategicamente estruturadas por lógicas de governo, especialmente quando se percebe que um controle exaustivo sobre os destinos dos escravos recém-libertos constitui o polo elementar de todo gesto abolicionista na perspectiva europeia.

Será possível descrever a figura do escravo - não o escravo abstrato das relações voluntárias dos europeus das terras temperadas, mas o escravo encarnado e espoliado das terras subtraídas ao gênio da liberdade europeia - como um ponto de singularização dessa razão governamental colonial universalista (europeia) que, mesmo quando alforria, o faz como um mecanismo necropolítico de gestão e contenção da liberdade? Operação em que a concessão da liberdade tem por função estratégica confinar os novos homens livres em uma condição de subalternidade civil e política? Eis o ponto em que reencontramos Michel Foucault e Achille Mbembe.

É certo que o conceito foucaultiano de biopoder - mesmo tensionado pela guerra das raças de que Foucault fala na última aula de Em defesa da sociedade (FOUCAULT, 2010) - não consegue explicar até o fim nem o colonialismo como tecnologia governamental planetária, nem o tecido de violências moleculares que deram 
consistência ao escravo negro (MBEMBE, 2018b). Achille Mbembe investiga as noções de raça, negro e África como suportes simbólico-materiais produzidos e reproduzidos por uma trama de saberes e poderes que deram forma a uma razão negra europeia progressivamente transnacionalizada; de nossa parte, aproveitamos suas descrições para analisar o escravo como um ponto de singularização e acúmulo de uma série de tecnologias de poder, que poderiam servir como grade de inteligibilidade para compreender a governamentalidade colonial e suas relações paradoxais com a abolição e a liberdade.

Entre os anos de 1976 e 1979, Michel Foucault definiu tanto a soberania quanto o biopoder como técnicas de poder sobre a vida, exercidas em escalas e sobre objetos muito heterogêneos. Até o século XVII, a soberania era descrita como um direito sobre a vida que se exercia de maneira desequilibrada, sempre do lado do poder de fazer morrer ou deixar viver, como epifenômeno terminal de um direito mais geral de espoliar e confiscar bens, serviços e trabalho dos súditos (FOUCAULT, 2009). O limite de um direito geral à espoliação era o confisco da vida por mero exercício do direito de gládio soberano.

Na medida em que o poder passa a se situar no horizonte das populações, é sinal de que ele passa a se exercer no nível "da vida, da espécie, da raça e dos fenômenos maciços [...]" (FOUCAULT, 2009, p. 150). Nesse momento, entre o século XVII e a segunda metade do século XVIII, sem que a lógica da soberania seja integralmente substituída, o poder sobre a vida vai se desdobrar em duas técnicas interligadas por um feixe de relações. Por um lado, as disciplinas; técnicas que terão por objetivo uma anátomopolítica do corpo dos indivíduos. Por outro, os dispositivos de segurança que incidem sobre o corpo biopolítico das populações na escala de sua economia biológica (FOUCAULT, 2009, p. 151-152).

Não é impossível perceber que os escravos sujeitos à lógica de governo colonial são constituídos em larga medida por um acúmulo de todas essas tecnologias de poder embora seu sentido unificador profundo pareça escapar-lhes essencialmente. Isso pode ser deduzido não apenas pela série de considerações com que o iluminismo liberal de 
Montesquieu analisou o escravo, mas também pelas descrições que Achille Mbembe (2018a) faz da gênese do sujeito racial como ser-outro vazio e negativo.

Se Michel Foucault (2009, p. 147) estivera certo em afirmar que o poder soberano e o direito de vida e morte "derivava formalmente da velha patria potestas que concedia ao pai de família romano o direito de 'dispor' da vida de seus filhos e de seus escravos", é preciso reconhecer que entre soberania e escravidão há muito mais do que um agenciamento acidental, mas uma relação genética ou estrutural. O escravismo consiste em uma tecnologia que subministra e difere o exercício do poder de matar pela espoliação do tempo de vida, dos bens e dos produtos do labor; agencia poder sobre a vida, que se exerce desequilibradamente do lado do poder de dar a morte, e confisco do corpo, do tempo e do trabalho útil. Isso confirma o que sustentamos mais cedo a partir de Aristóteles, que a verdade da soberania e o sustentáculo original da autoridade política é o escravo. Eis o que faz do súdito e do cidadão graus intermediários de sujeiçãoliberdade em relação aos extremos que explicariam sua natureza mais profunda - o escravo e o soberano.

Subordinados à economia extrativista e agrária, ou à servidão doméstica (MBEMBE, 2018a), os escravos negros estavam também sujeitos a uma série de disciplinas de caráter pré ou protoindustriais aplicadas à docilização de seus corpos e extração de trabalho útil, que não raro assumiam o caráter de castigos físicos espectaculares e atrozes. Sob esse ponto de vista, não seria absurdo enxergar o escravo como o pressuposto evanescente do trabalhador livre. Talvez por isso Achille Mbembe (2018b, p. 18) sustente que "mais do que o pensamento de classe [...], a raça foi a sombra sempre presente no pensamento e na prática das políticas do Ocidente [...]”. As “disciplinas coloniais" seriam, nesses termos, formas nada próximas da sutileza pervasiva das disciplinas europeias que Foucault descrevera, mas técnicas de poder que se beneficiaram da articulação entre a racionalidade instrumental, produtiva e administrativa da modernidade ocidental, embora o próprio Mbembe (2018b) tenda a descrever a economia de atrocidades e sevícias das plantations como uma manifestação biopolítica do terror e do estado de exceção. 
Por fim, o poder sobre a vida se exerce na carne do escravo, a partir da indeterminação entre soberania (o poder de fazer morrer e deixar viver) e biopolítica (o poder de fazer viver e deixar morrer). Eis porque o conceito de biopolítica foucaultiano já não pode dar conta até o fim de seus traços necropolíticos: a escravidão é um dispositivo de poder que funciona menos como comutação da morte pela sujeição absoluta do que como forma instrumental de administrar o poder de matar na duração virtualmente infinita, extorquindo o labor de um corpo e seus produtos. O escravo não é aquele que troca a morte por uma forma sujeitada de continuar vivendo, mas aquele cuja morte é uma virtualidade que se atualiza sob a forma do adiamento infinito, até o limite corporal de seu vigor e forças.

Se, de fato, não seria possível ver no "sonho genocida da modernidade europeia" (FOUCAULT, 2009, p. 149-150) uma reabilitação pura e simples do direito de gládio soberano, mas um deslocamento que conduziria à biopolítica das populações, é porque os genocídios modernos - a começar pelos colonialismos - constituem uma experiência original, extrema e transnacional de necropoder cujo operador privilegiado é o racismo como "tecnologia destinada a permitir o exercício do biopoder", reguladora da “distribuição da morte” (MBEMBE, 2018b, p. 18).

O escravo é, portanto, produzido por uma trama cerrada de coerções micro e macropolíticas; um ponto de singularização formado pela acumulação e pelo curtocircuito de tecnologias soberanas (poder de morte e de espoliação), ao mesmo tempo pré, proto e ultradisciplinares (um denso sistema de coerções e castigos físicos espetaculares e atrozes) e biopolíticos (os negros são traficados, vendidos, instrumentalizados, geridos e controlados como populações transnacionais de escravos). ${ }^{3}$

É muito pouco, portanto, dizer que o escravo possui o estatuto de uma coisa ou ferramenta viva. A escravidão moderna se caracteriza pela produção do escravo negro

\footnotetext{
3 Nesse mesmo sentido, Mbembe (2018a, p. 75) atesta que o regime da plantation implicava uma bioeconomia, e que nele "O trabalho e a produção das riquezas eram inseparáveis dos problemas específicos da vida e da população, da regulação dos movimentos e dos deslocamentos; em suma, dos processos de circulação e de captura. E os processos de circulação e de captura representavam uma dimensão crucial tanto das tecnologias de segurança quanto dos mecanismos de inscrição das pessoas nos sistemas jurídicos-legislativos diferenciados".
} 
tanto como forma quanto como carne; tanto como fantasma quanto como relação social. ${ }^{4}$ Achille Mbembe (2018a, p. 41) recorda que o século XVIII gerou uma série de saberes que não cessaram de representar o negro como "o protótipo de uma figura préhumana incapaz de escapar de sua animalidade"; por outro lado, esse "corpo gigantesco e fantástico" do negro, segundo a imaginação colonial hegeliana (MBEMBE, 2018a, p. 80), era submetido a um processo de destituição cívica que terminava por reduzi-lo à condição legal de um bem móvel (MBEMBE, 2018a).

Ante o escravo negro arrostamos muito mais do que a consecução radical da instrumentalização proprietária do homem pelo homem. A verdade que o escravo encarna sobre a soberania política é que a condição para que o homem seja o lobo do homem é que, muito antes, o homem possa ter sido o roubo do homem. O escravo exprime uma consistência política, social, ontológica, jurídica e econômica que se manifesta como realidade muito espectral dos escravos, mesmo na condição de homensobjeto, metal, mercadoria, moeda. Por isso, Mbembe (2018a, p. 68) sustenta que a descrição do sujeito racial como um efeito de um encadeamento de tecnologias de poder heterogêneas não é suficiente; "Não basta dizer que a raça não tem nenhuma essência". Ela é uma forma de afirmar o poder e, a um só tempo, opera enquanto afeto comum e “estrutura imaginária” sem compromissos com a realidade (MBEMBE, 2018a, p. 69). A raça encerraria uma espécie de simulacro, ou de espectro, que separa conjuntos de corpos de sua espessura real, ao mesmo tempo em que penetra e constitui as dimensões sensíveis do real que falsifica, fabricando os afetos e a fixação psicopatológica que a ele estarão ligados no contexto dos racismos. Nesse sentido, o paradoxo do racismo é encerrar uma política que precede a ontologia, cujo efeito consiste em prender o negro a uma silhueta separada de sua essência, condenando-o a habitar esse vazio (MBEMBE, 2018a, p. 69-70).

O negro não passa, pois, de uma fantasia social efetiva, uma "figuração da brutalidade e da crueldade, de uma forma singular da predação e de uma capacidade

\footnotetext{
4 "[....] o negro", sustenta Mbembe (2018a, p. 42), "não existe enquanto tal. Ele é constantemente produzido. Produzi-lo é gerar um vinculo social de sujeição e um corpo de extração, isto é, um corpo inteiramente exposto à vontade de um senhor e do qual nos esforçamos para obter o máximo de rendimento".
} 
inigualada de sujeição e de exploração de povos estrangeiros" (MBEMBE, 2018a, p. 91). Ele é a memória de uma perda e de uma usurpação que prossegue no presente. Isso é dizer que o negro - assim como o branco - não existe enquanto tal; não passa de uma fantasia do branco que suspende a sua humanidade impondo-lhe a condição de mercadoria, objeto de luxo e utilidade.

Que ao negro se atribua, na modernidade, a forma jurídica e econômica da propriedade móvel, ou semovente (dada sua pretensa animalidade incivil), da mercadoria ou da moeda, assumindo a forma do equivalente universal das trocas, não é algo isento de consequências. Nos séculos XVIII e XIX, a mecadoria corresponde à forma "mais geral e mais elementar da produção burguesa" (MARX, 2017, p. 104). À estrutura evanescente de seu fictício ser negro, à anatomia fetichista de seu corpo útil, corresponde o elemento fantasmático e material das mercadorias e moedas que obscurecem o caráter social e político originário das relações de governamentalidade colonial, um pouco como em 0 capital a forma metafísica do equivalente geral obscurecia a relação social capitalista entre homens, assumindo "a forma fantasmagórica de uma relação entre coisas" (MARX, 2017, p. 94). É precisamente essa forma jurídica, econômica, correspondente à consistência social e política das relações escravistas, que será progressivamente alterada pela liberdade governamentalizada no Brasil pós-abolição como estratégia apta a reproduzir a consistência ontológica, fantasmática e espectral do ser negro.

\section{Governar pela liberdade: o trabalhador e o imigrante no Brasil pós-abolição}

Para estimar em toda a sua extensão a afirmação de Florestan Fernandes (1979, p. 54), segundo a qual "ao desaparecer, o trabalho escravo deixou atrás de si várias formas de trabalho semilivre e de trabalho escravo disfarçado que continuam a existir até hoje", em sua relação com a experiência colonial brasileira, é preciso compreender de que maneira o processo de abolição constituiu uma estratégia governamental que teve por objeto a liberdade dos escravos no Brasil.

O primeiro passo na direção da abolição da escravidão no Brasil consistiu na formalização da extinção do tráfico negreiro, adotado legalmente a partir de 1831 sob as 
pressões da Inglaterra, que o exigiu através da renovação de tratados comerciais com o Brasil, um país de economia agrária baseada no trabalho servil (PRADO JÚNIOR, 1994) no qual desembarcavam, àquele tempo, anualmente 40.000 escravos. A lei de 1831 permanece letra morta até o ano de 1850, quando a Lei Eusébio de Queirós estabelece medidas para a repressão do tráfico de africanos no Império brasileiro, combatendo "interesses mercantis poderosos, e [...] o constante argumento dos partidários eternos do status quo, dos que, temerosos do futuro incerto e insondável, só querem, a qualquer custo, o repouso permanente das instituições" (HOLANDA, 2014, p. 87).

No decorrer das décadas seguintes, a extinção do tráfico negreiro atinge o elemento até então indispensável ao modo de produção nacional. O fim do tráfico e do comércio de escravos, mesmo "após duas décadas de ilegalidade tolerada pelas autoridades brasileiras" (BALÁN, 1973, p. 10), somada à elevada taxa de mortalidade, fugas e suicídios, determinou uma crise generalizada da mão de obra disponível. Dos três milhões de escravos que ingressaram no Brasil ao longo do século XIX, havia restado apenas um milhão e meio em 1872 - número que decresceu até 1888 ( BALÁN, 1973). Esse contexto justificava a inobservância da Lei Eusébio de Queirós sob o argumento de que “em país novo e mal povoado como o Brasil, a importação de negros, por mais algum tempo, seria, na pior hipótese, um mal inevitável, em todo o caso diminuto, se comparado à miséria geral que a carência de mão de obra poderia produzir" (HOLANDA, 2014, p. 88).

Esse quadro era ainda agravado porque "os trabalhadores livres ou os escravos libertos se recusavam a trabalhar como assalariados ao lado de escravos, preferindo a miséria à desqualificação social que isso implicava” (BALÁN, 1973, p. 12), mas também porque os fazendeiros - que a esse tempo utilizavam simultaneamente mão de obra escrava e livre - preferiam expor os trabalhadores livres às atividades que comportavam risco de morte, a fim de preservar o valor de sua propriedade escrava (COSTA, 2010). Isso faz nascer toda uma economia de migrações de populações negras, favorecendo o deslocamento de escravos para regiões mais prósperas, especialmente no sentido do eixo Norte-Sul do Brasil. Ao lado de uma economia de migrações escravistas, terão lugar algumas iniciativas para proporcionar a imigração de estrangeiros a partir de 1850, dando 
início à "segunda vertente da constituição biopolítica do proletariado latino-americano: as imigrações" (NEGRI; COCCO, 2005, p. 81).

Nos anos 1870, enquanto "a grande lavoura continuava a depender do escravo, nas cidades, o trabalhador livre substituía o escravo" (COSTA, 2010, p. 38). Com o início da indústria manufatureira no Brasil, as classes dominantes constatavam a "ineficiência para os serviços mais delicados e complexos de manufaturas" (PRADO JÚNIOR, 1994, p. 175) e a "vantagem financeira maior que representa na indústria o pagamento de salários em vez do preço de escravos". A esse tempo, era comum ler em jornais paulistas artigos como o de José Vergueiro, que considerava que o investimento do capital nacional deveria ser aplicado em salários de trabalhadores livres tendo em vista o custo incomparavelmente alto dos escravos, "as despesas com alimentação, vestuário, assistência médica e juros sobre o capital empatado" (COSTA, 2010, p. 68).

O sistema de parcerias entre fazendeiros e os primeiros imigrantes europeus, em paralelo com o prosseguimento da exploração da mão de obra escrava, favoreceu a formação do primeiro conjunto relevante de trabalhadores livres e assalariados do Brasil. Imigrantes europeus eram inseridos nas fazendas de café brasileiras, buscados por membros da elite econômica e política nacional, e se obrigavam a pagar as dívidas de seu deslocamento, instalação e respectivos juros com trabalho "livre" (COSTA, 2010, p. 35). Enquanto isso, entre os anos de 1851 e 1852, o Estado brasileiro avançava na estratégia da alforria da população negra a partir de um horizonte de controle biopolítico, consistente na multiplicação de projetos de lei "visando à liberdade dos nascituros e à obrigatoriedade da alforria dos escravos pelos quais se oferecesse o respectivo preço" (PRADO JÚNIOR, 1994, p. 173-174).

Progressivamente, a lógica do escravismo cede lugar à do trabalho coagido em condições de aparente liberdade; não apenas porque este era mais viável e lucrativo, mas porque uma complexa conjuntura política - em que os proprietários de escravos perdiam lentamente seu poder de influência -, jurídica (com a adoção da Lei do Ventre Livre, de 1871, por exemplo) (PRADO JÚNIOR, 1994), local e internacional, dirigia a estratégia da abolição. 
A Lei do Ventre Livre é um evidente exemplar de uma operação colonial em que a liberdade é confinada a uma estratégia de governo biopolítico que a toma como elemento governável. Por um lado, a Lei de 1871 decretava a liberdade dos filhos de escravos nascidos após sua vigência; por outro, impunha que vivessem sob a tutela dos proprietários dos pais até que atingissem a maioridade, com a possibilidade de usufruírem de seus serviços (PRADO JÚNIOR, 1994). Na prática, a lei mantinha os filhos presuntivamente livres de escravos sob a tutela servil dos proprietários de escravos; de modo que essa lei não tinha por objeto conceder liberdade, mas adequar a progenitura negra à estrutura escravocrata existente sem grandes rupturas, a partir da alteração de uma condição jurídica (que também viria a ser econômica e política) por meio da intervenção do Estado sobre o elemento da natalidade da população de escravos negros.

Em 8 de maio de 1888, Rodrigo Augusto da Silva, então Ministro da Agricultura, apresentou à Câmara dos Deputados uma proposta do Executivo que extinguia a escravidão no Brasil (COSTA, 2010). A proposta obteve aprovação tanto na Câmara como no Senado e, em 13 de maio de 1888, foi encaminhada à Regente, Princesa Isabel, que a ratificou. Seu efeito foi transformar repentinamente mais de 700 mil escravos, majoritariamente concentrados nas províncias do sudeste do país, em homens livres, isto é, trabalhadores indesejáveis, pois "o braço livre desejado era o braço estrangeiro, sem mácula, não o braço do liberto ou do negro degradado pela escravidão" (CARDOSO, 1962, p. 22).

Da sua condição escrava original para a de trabalhador livre - que continuava a viver nas antigas senzalas -, nada mudou, exceto o cadeado e o repentino desaparecimento da garantia da subsistência, na medida em que cessavam as obrigações dos antigos amos "de vestir e alimentar seus escravos. Agora ele[s] Ihes vendia[m] os suprimentos, até mesmo o leite e a couve que consumiam" (COSTA, 2010, p. 135). O antigo escravo se encontrava, assim, convertido "sumária e abruptamente, em senhor de si mesmo [...]" (FERNANDES, 2008, p. 29), de modo que a sua liberdade tão tardia quanto 
abrupta não representava na prática nada além de um novo passo na lógica da “espoliação extrema e cruel”. 5

A abolição é o catalisador de um novo ciclo de imigrações que servirá de quadro econômico-social à ideologia de fundo racista do branqueamento da população brasileira. Em 1888, o Brasil registra o ingresso de 133.000 imigrantes - mais que o dobro do ano anterior - e manterá até o final do século uma média de 100.000 imigrantes por ano. A imigração, que deixa de ser uma prática privada dos fazendeiros e passa a ser gerida e subvencionada pelo Estado brasileiro, constituirá um dos mais fortes elementos de desarticulação do sistema escravista, tornando o trabalho livre (e branco) a regra (PRADO JÚNIOR, 1994). Esse conjunto de trabalhadores livres será organizado - especialmente em subordinação à economia cafeeira - segundo uma lógica de expropriação, remunerações urdidas à subsistência e submetidas ao controle central do fazendeiro (FRANCO, 1997).

Mbembe (2018a, p. 124) tem razão em afirmar que "o Estado colonial opera por meio da estatização do biológico". Uma espécie de "europeização demográfica" de Estados como São Paulo, que em 1897 tinha dois italianos para cada brasileiro (DOMINGUES, 2002, p. 568), foi um dos efeitos dessa biopolítica imigratória de branqueamento, delegada pela Constituição da República de 1891 aos Estados. Na medida em que o trabalhador livre e o imigrante branco passam a coincidir no entrecruzamento de uma política de Estado de imigração e de desenvolvimento do mercado interno e laboral, é possível perceber que é nos termos da emergência de um biopoder que o racismo é inserido dos mecanismos de Estado (FOUCAULT, 2010), ou que o racismo é uma técnica que torna possível o exercício do biopoder (MBEMBE, 2018b).

No caso brasileiro pós-abolição, o processo “irreversível” de branqueamento da população (DOMINGUES, 2002, p. 566) representava a coincidência entre um convênio

\footnotetext{
${ }^{5}$ Florestan Fernandes (2008, p. 35-36) sustenta, ainda, que ao longo deste período "a sociedade brasileira largou o negro ao seu próprio destino, deitando sobre seus ombros a responsabilidade de se reeducar e de se transformar para corresponder aos novos padrões e ideais de ser humano", em desgastante adaptação ao "advento do trabalho livre, do regime republicano e do capitalismo", conjuntura na qual se deu a total modificação da estrutura de consideração do negro enquanto agente de trabalho pela exclusão que privilegiou sujeitos dominantes como o "fazendeiro" e o "imigrante".
} 
entre Estado e mercado que origina uma biopolítica das populações (na medida em que o branqueamento constituía, segundo sua ideologia racista, a ponte para um aprofundamento do processo civilizatório nacional) (VAINER, 1995), anexada a uma estratégia necropolítica das populações negras. Tratava-se, com efeito, de produzir seu desaparecimento. Nesse tempo, previa-se que o fluxo migratório de trabalhadores livres europeus extinguiria os negros em no máximo 200 anos (SILVA, 2012). A biopolítica das populações, apesar de implicar uma forma de exercício de poder positiva e fabril sobre a vida das populações, possui quase sempre um duplo que tangencia o necropoder dos extermínios, genocídios ou etnocídios planificados pelos Estados.

É uma guerra de raças que se encontra sob a biopolítica imigratória de branqueamento no Brasil pós-abolição. O racismo constitui a introdução de um corte entre o que deve viver (os brancos, semi-brancos, quase-brancos, sub-brancos) e o que deve morrer (todos aqueles cujo fato de viver contribui para o enegrecimento da população). Eis o sentido mais profundo da afirmação de Florestan Fernandes (1972, p. 47), segundo a qual a abolição não passou de uma "uma revolução social feita pelo branco e para o branco". Os brancos só não contavam com o devir-negro em que a abolição, genuína estratégia de uma liberdade governada, os lançaria, especialmente na medida em que "ao desaparecer, o trabalho escravo deixou atrás de si várias formas de trabalho semilivre e de trabalho escravo disfarçado que continuam a existir até hoje" (FERNANDES, 1979, p. 54).

\section{Considerações finais. Tocar o tempo presente: o devir-negro do Brasil pós- abolição}

Achille Mbembe (2018a; 2018b) não cessa de afirmar, a contrapelo de Marx, que a virtual desaparição de uma sociedade de classes não conduz necessariamente à desaparição da raça como limiar de distinção entre aqueles que devem viver e os que devem morrer. Isso porque a colonização foi originalmente a expressão de uma guerra entre raças (MBEMBE, 2018a) que assumiu proporções planetárias e que, ainda hoje, não parece ter chegado a seu termo. Eis o que indica a urgência de tocar o tempo presente: "perseguir na vida de hoje os sinais que indicam esses retornos do colonialismo ou de sua 
reprodução e sua repetição nas práticas contemporâneas" (MBEMBE, 2018a). Fazer um uso político da memória escrava do Brasil pós-colonial que não seja meramente reprodutiva de seus princípios. Todos os elementos do potentado colonial, exceto talvez ele próprio - hoje difundido segundo as "lógicas de distribuição da violência em escala planetária" e a "vasta operação em curso de depreciação das forças produtivas" (MBEMBE, 2018a, p. 309) - ainda permanecem vivos nas sociedades neoliberais, especialmente as que se encontram na província do mundo.

De Montesquieu à Princesa Isabel, do Iluminismo universalista europeu ao imaginário governamental das economias neocoloniais, é necessário urdir os fios que ligam necropoliticamente o liberalismo europeu e a sua expansão imperial. Neles, a liberdade afigura-se um elemento a ser regulado, contido, confinado, subministrado parcimoniosamente no interior de uma ordem mundial que se já não é colonial, tampouco pode ser chamada de pós-colonial. A memória do período abolicionista brasileiro permite demonstrar que a abolição não passou de uma operação jurídica, política, econômica e social que não apenas não visava à libertação dos escravos, mas à imposição de uma liberdade no abandono (no sentido em que Jean-Luc Nancy ou Giorgio Agamben empregam esse termo) $)^{6}$, bem como à extinção da população negra em um prazo determinado por uma estratégia bio-necropolítica de branqueamento dirigida por um convênio entre Estado e Mercado ao longo do século XIX.

Na medida em que se passa do trabalho escravo ao livre, não apenas a escravidão - como estrutura elementar do modo de produção - não desaparece, mas é tensionada como verdade efetiva e profunda do modelo de trabalho livre. A liberdade no abandono conferida aos novos livres corresponde à face excludente das condições relativamente proporcionais de desterro, endividamento radical e espoliação contratual dos imigrantes de origem europeia, incluídos na economia legal brasileira do século XIX. Como demonstramos, o discurso europeu sobre a legitimidade da escravidão durante a modernidade sempre esteve às voltas com elementos como o meio e a terra, a natureza e o temperamento dos homens e das populações, o contrato voluntário pelo qual um escravo constitui legitimamente para si um senhor, a dívida radical de vida e morte que

\footnotetext{
${ }^{6}$ Cf., nesse aspecto, Giorgio Agamben (2007) e NANCY (1983).
} 
tem para com seu amo, o trabalho como contraprestação pela subsistência (viés econômico do mero fato de viver) etc. Precisamente o conjunto dos elementos que iremos reencontrar mobilizados e transformados entre os imigrantes europeus brancos que chegaram ao Brasil no último terço do século XIX.

Com a substituição do trabalho escravo pelo sistema de parcerias entre fazendeiros e trabalhadores livres (em larga medida coincidentes com os imigrantes europeus) e, mais tarde, com a abolição, as políticas estatais de imigração europeia e a adoção do modelo do trabalho livre e assalariado, o escravo não deixa de existir; deslocado pela economia do trabalho livre, torna-se a sombra da transfigurada forma jurídica do parceiro agrícola ou do trabalhador assalariado, cujas condições materiais de vida eram, quando não piores, relativamente equivalentes às dos escravos.

O advento do trabalho assalariado não implicou a liberdade do antigo escravo negro, mas a captura do trabalhador livre e branco pela lógica colonial eufemizada em condições equivalentes ou inferiores à dos escravos. De modo análogo, a norma de subjetivação do sujeito neoliberal contemporâneo constitui uma nova trama na urdidura do devir-negro do mundo. O tempo presente das sociedades neoliberais - "empresas constituídas de empresas" (DARDOT; LAVAL, 2016, p. 321-322), e não mais de indivíduos no sentido liberal clássico -, é aquele em que também os homens encontram-se sujeitos a mecanismos de subjetivação inéditos e a uma nova economia psíquica em que o gozo, o consumo e a produção se tornam elementos de uma autorregulação desses sujeitosempresa. É o caráter livre, autônomo, autoimposto, autogerido, empreendedor e pessoal do trabalho em comum que será vampirizado por modos de colonização do desejo que curto-circuitam o hedonismo do consumo e o ascetismo do trabalho.

Assim como a abolição está para o sistema colonial como um elemento de liberdade a ser inserido na vida social de maneira controlada e administrada, uma relação ascética do sujeito empresarial contemporâneo sustenta a sua espoliação com base em sua própria autonomia organizativa laboral. Essencialmente, o si-mesmo é submetido à lógica de empresa, “injunge-se o sujeito a conformar-se intimamente, por um trabalho interior constante [...]"(DARDOT; LAVAL, 2016, p. 330); ele deve ser o mais eficaz possível, 
autoenvolver-se com o trabalho, aperfeiçoar-se sem cessar, ser flexível e poroso às incessantes mudanças impostas pelo mercado.

A liberdade é a estratégia central desse novo ethos social, que só pode configurarse na medida em que o "o indivíduo souber ultrapassar o estatuto passivo do assalariado [...], se ele souber se tornar uma empresa de si mesmo" (DARDOT; LAVAL, 2016, p. 334), em que a cisão entre a vida pessoal e a vida pessoal se apaga na ascese do desempenho. A dívida (de vida e morte do escravo, de expatriação dos trabalhadores livres imigrantes) continua a ser o componente que permite extrair a submissão desejável ao trabalho espoliado (LAZZARATO, 2017).

A forma jurídica sob a qual o trabalho era prestado e economicamente rapinado pelo potentado colonial, no alvorecer do liberalismo europeu, continua a reproduzir a guerra entre as raças em cada um de seus menores deslocamentos. Entre a condição do escravo, do trabalhador livre, do precário e do empresário de si mesmo - levado a abandonar desejosamente a posição de trabalhador livre para se tornar um prestador de serviços que compete abertamente no mercado mundial pela preferência dos consumidores -, há uma similitude material que faz dos três últimos um grau de realização subordinada ao primeiro.

O empresário de si é aquele que interiorizou não apenas o senhor, mas o feitor, a consciência da dívida (sob a forma muito espiritual da culpa), a correlação entre sua disposição laboral e o meio (o mercado mundial em regime de competição), a contínua contratualização das relações laborais cada dia mais desreguladas, a coincidência entre o trabalho e a espessura da vida individual. Como a empresa é "uma alma, um gás" (DELEUZE, 2008, p. 221), o trabalho é para o empresário de si a interiorização do que foi para os escravos: a lenta, virtualmente infinita, administração de uma morte diferida, com a diferença de que à sombra da morte se superpõe o fantasma da vida, na medida em que o trabalho, confundindo-se com ela, é cumulado pelas componentes de uma nova economia psíquica que ligam o desejo à sujeição e ao gozo, e a produção ao consumo.

O fato de a forma jurídica do que Achille Mbembe chamou de homem-metal, homem-objeto, homem-mercadoria, homem-moeda, para designar o escravo, já não 
existir entre nós, não deveria constituir um sinal de que a escravidão desapareceu de uma vez por todas. Deveria, antes, soar como o aviso de incêndio que denota que toda forma de trabalho espoliado se funda na fantasmática figura do escravo. Quando a formaescravo desaparece historicamente, quando mais nenhum homem pode ocupar a forma do equivalente geral das trocas, é porque, talvez, todos os trabalhadores do mundo tenham sido tomados em um devir-negro, e ocupem, hoje, de direito, a condição muito material de escravos informes. Eis a condição virtualmente comum ao trabalhador livre e ao empresário de si, ao cidadão como ao imigrante: ser tomado em um devir-negro, habitar em algum ponto a ausência de obra e a espessura negativa escrava que percorre o mundo das sociedades neoliberais como um fantasma difuso e total.

No seio de uma divisão planetária do trabalho espoliado que teve início com a expansão colonial europeia (MBEMBE, 2018a), que se caracteriza pelo aprofundamento de sua desregulação, pela multiplicação de fluxos migratórios de homens que devémnegros no sistema internacional da partilha necropolítica daqueles que podem viver ou devem morrer, e que na melhor da hipóteses entrega-nos o empresário de si como forma mais bem sucedida do que o trabalhador livre se tornou em nosso tempo, seria preciso reconhecer que o devir-negro do mundo não é apenas o que nos espera. É o que, desde a invenção do dispositivo da raça, jamais deixou de nos acontecer.

\section{Referências}

AGAMBEN, Giorgio. Homo sacer: o poder soberano e a vida nua I. Tradução de Henrique Burigo. Belo Horizonte: Editora UFMG, 2007.

AGAMBEN, Giorgio. Infância e história: destruição da experiência e origem da história. Tradução de Henrique Burigo. Belo Horizonte: Editora UFMG, 2008.

AGAMBEN, Giorgio. O uso dos corpos (Homo sacer IV, 2). Tradução de Selvino J. Assmann. São Paulo: Boitempo, 2017. 
AREND, Silvia Maria Fávero; MACEDO, Fábio. Sobre a história do tempo presente:

Entrevista com o historiador Henry Rousso. Revista Tempo e Argumento, Florianópolis, v. 1, n. 1, p. 201-216, jan./jun. 2009

ARENDT, Hannah. A condição humana. 11 ed. Tradução de Roberto Raposo. Rio de Janeiro: Forense Universitária, 2010.

ARISTOTE. Les politiques. Traduit par Pierre Pellegrin. Paris: Flammarion, 1993.

BALÁN, Jorge. Migrações e desenvolvimento capitalista no Brasil: ensaio de interpretação histórico-comparativa. Estudos Cebrap, São Paulo, n. 5, 3. sem. 1973.

BÉDARIDA, François. Tempo presente e presença da história. In: FERREIRA, Marieta de M.; AMADO, Janaína. Usos e abusos da história oral. 5.ed. Rio de Janeiro: Ed. FGV, 2002.

CARDOSO, Fernando Henrique. Capitalismo e escravidão no Brasil meridional. São Paulo: Difusão Europeia do Livro, 1962.

COSTA, Emília Viotti da. A abolição. 9. ed. São Paulo: Editora Unesp, 2010.

DARDOT, Pierre; LAVAL, Christian. A nova ordem do mundo: ensaio sobre a sociedade neoliberal. Tradução de Mariana Echalar. São Paulo: Boitempo, 2016.

DELEUZE, Gilles. Conversações. Tradução de Peter Pál Pelbart. São Paulo: Editora 34, 2008.

DOMINGUES, Petrônio José. Negros de almas brancas? A ideologia do branqueamento no interior da comunidade negra em São Paulo, 1915-1930. Estud. afro-asiát., Rio de Janeiro, v. 24, n. 3, p. 563-600, 2002. Disponível em: http://www.scielo.br/ scielo.php?script=sci_arttext\&pid=S0101-546X2002000300006\&lng=en\&nrm=iso. Acesso em: 28.abr. 2018.

FERNANDES, Florestan. A integração do negro na sociedade de classes: vol. 1. 5.ed. São Paulo: Globo, 2008.

FERNANDES, Florestan. Circuito fechado: quatro ensaios sobre o "poder institucional". 2. ed. São Paulo: Hucitec, 1979.

FERNANDES, Florestan. O negro no mundo dos brancos. São Paulo: Difusão Europeia do Livro, 1972.

FRANCO, Maria Sylvia de Carvalho. Homens livres na ordem escravocrata. 4. ed. São Paulo: Fundação Editora da Unesp, 1997. 
FOUCAULT, Michel. Em defesa da sociedade.. Tradução de Maria Ermantina de Almeida Prado Galvão. São Paulo: Martins Fontes, 2010.

FOUCAULT, Michel. História da sexualidade I: a vontade de saber. 19 ed. Tradução de Maria Thereza da Costa Albuquerque e J. A. Guilhon Albuquerque. Rio de Janeiro: Graal, 2009.

FOUCAULT, Michel. Segurança, território, população. Tradução de Eduardo Brandão. São Paulo: Martins Fontes, 2008.

HEGEL, Friedrich Wilhelm. Princípios da filosofia do direito. Tradução de Orlando Vittorino. São Paulo: Martins Fontes, 1997.

HOBBES, Thomas. Do cidadão. Tradução de Renato Janine Ribeiro. São Paulo: Martns Fontes, 2002.

HOBBES, Thomas. Leviathan, or the matter, forme and power of a common-wealth ecclesiastical and civil. London: Penguin Books, 2017.

HOBSBAWM, Eric J. Un historien et son temps présent. In: INSTITUT d'Histoire du Temps Présent. Ecrire l'histoire du temps présent. Paris: CNRS Ed., 1993.

HOLANDA, Sérgio Buarque de. Raízes do Brasil. 27. ed. São Paulo: Companhia das Letras, 2014.

LAPOUJADE, David. Puissances du temps: versions de Bergson. Paris: Les Éditions de Minuit, 2010.

LAZZARATO, Maurizio. O governo do homem endividado. Tradução de Daniel P. P. Da Costa. São Paulo: n-1 edições, 2017.

LOCKE, John. Dois tratados sobre o governo. Tradução de Julio Fischer. São Paulo: Martins Fontes, 2005.

MARX, Karl. O capital: crítica da economia política (Livro I). 35 ed. Tradução de Reginaldo Sant'Anna. Rio de Janeiro: Civilização Brasileira, 2017.

MBEMBE, Achille. Crítica da razão negra. Tradução de Sebastião Nascimento. São Paulo: n-1 edições, 2018a.

MBEMBE, Achille. Necropolítica: biopoder, soberania, estado de exceção, política da morte. Tradução de Renata Santini. São Paulo: n-1 edições, 2018b.

MONTESQUIEU, Charles de Secondat. O espírito das leis. 3. ed. Tradução de Cristina Murachco. São Paulo: Martins Fontes, 2005. 
NEGRI, Antonio; COCCO, Giuseppe. GlobAL: biopoder e lutas em uma América Latina globalizada. Rio de Janeiro: Record, 2005.

NIETZSCHE, Friedrich Wilhelm. De l'utilité et des inconvénients de l'histoire pour la vie. In: NIETZSCHE, Friedrich Wilhelm Considérations inactuelles I et II. Traduit par Pierre Rusch. Paris: Gallimard, 1990, p. 91-169.

PRADO JÚNIOR, Caio. História econômica do Brasil. 41. ed. São Paulo: Brasiliense, 1994.

RANCIÈRE, Jacques. O deentendimento: política e polícia. Tradução de Abgela Leite Lopes. São Paulo: Editora 34, 1996.

RICEEUR, Paul. A memória, a história, o esquecimento. Tradução de Alain François et al. Campinas: Editora UNICAMP, 2007.

VITÓRIA, Francisco. Os índios e o direito da guerra. Tradução de Ciro Mioranza. ljuí: Editora Unijuí, 2006. 